\title{
Pre-Clinical Trial Site Evaluation Report
}

National Cancer Institute

\section{Source}

National Cancer Institute. Pre-Clinical Trial Site Evaluation Report. NCI Thesaurus. Code C115586.

Records describing an onsite visit, or other contact experience to determine whether a site is qualified to participate in a clinical trial. 